\section{Interspecific Hybridization in Clethra}

\author{
Sandra M. Reed ${ }^{1}$
}

Floral and Nursery Plants Research Unit, U.S. National Arboretum, Agricultural

Research Service, U.S. Department of Agriculture, Tennessee State University

Nursery Crop Research Station, 472 Cadillac Lane, McMinnville, TN 37110

\section{Younghee Joung ${ }^{2}$ and Mark Roh ${ }^{3}$ \\ Floral and Nursery Plants Research Unit, U.S. National Arboretum, Agricultural \\ Research Service, U.S. Department of Agriculture, 10300 Baltimore Avenue, Beltsville, MD 20705 \\ Additional index words. summersweet, sweet pepper bush, RAPD markers, C. acuminata, C. alnifolia, C. fargesii, C. pringlei}

\begin{abstract}
The genus Clethra contains many ornamental species, of which the most adaptable and cold hardy is $C$. alnifolia $\mathrm{L}$. The objective of this study was to obtain hybrids between $C$. alnifolia and three other ornamental Clethra species, $C$. acuminata Michx., $C$. fargesii Franch., and $C$. pringlei $\mathrm{S}$. Wats. Viable plants were obtained from reciprocal crosses between $C$. alnifolia and $C$. fargesii, and from crosses between $C$. alnifolia and the other two species when $C$. alnifolia was used as the maternal parent. Randomly amplified polymorphic DNA (RAPD) markers were used to verify hybridity and to compare hybrids to their parents. In all cases, the hybrids had more RAPD markers in common with $C$. alnifolia than with their other parent. Close clustering by neighbor-joining analysis of RAPD markers and the morphological resemblance of $C$. alnifolia $\times C$. acuminata and $C$. fargesii $\times$ C. alnifolia plants to their paternal parent indicated that these plants were of hybrid origin. The $C$. alnifolia $\times C$. pringlei plants resembled $C$. alnifolia in many respects, but they stayed green much later in the year than did $C$. alnifolia with leaves remaining on the plants throughout the winter. These foliage characteristics were presumed to reflect the contribution of the evergreen $C$. pringlei, and thus were regarded as evidence of hybridity.
\end{abstract}

The genus Clethra is the sole member of the Clethraceae family (Rehder, 1987). It is comprised of $\approx 70$ species of deciduous and evergreen shrubs or small trees (Sleumer, 1967) with an Asiatic-American distribution. The largest numbers of species are found in China and Mexico (Hu, 1960), but members of the genus are also native to the eastern United States, Central and South America, and Madeira. Closely related to the Ericaceae, Clethra species require an acidic soil and produce small, fragrant flowers in long racemes or panicles in mid-summer.

Clethra alnifolia, commonly known as sweet pepperbush or summersweet, is the mostly widely grown of the Clethra species in the U.S. It ranges from Maine to Florida to coastal Texas (Wilbur and Hespenheide, 1967) and is valued for its lustrous deciduous foliage, extremely fragrant flowers, and wide adaptability. The species is hardy from USDA zone 4 to 9 , can grow in open sun or as an understory plant, and is adapted to coastal or swampy conditions (Dirr, 1998). A southern form, C. alnifolia var. tomentosa Michx., is

Received for publication 18 Dec. 2000. Accepted for publication 30 May 2001. Mention of trade names of commercial products in the publication is solely for the purpose of providing specific information and does not imply recommendation or endorsement by the U.S. Dept. of Agriculture.

${ }^{1}$ Research Geneticist.

${ }^{2}$ Visiting Scientist. Current address: Korea Research Institute of Bioscience and Biotechnology, P.O. Box 115, Yusong, Taejeon 305-600, Chungnam, Korea. ${ }^{3}$ Research Horticulturist. often considered to be a separate species, $C$. tomentosa Lam. (Dirr, 1998).

While many desirable and superior characteristics are present among the various Clethra species, no work has been published concerning hybridization in this genus. The objective of this research was to utilize interspecific hybridization to develop Clethra cultivars that have unique combinations of desirable traits. Because C. alnifolia is the most adaptable and cold-hardy member of the genus, this work focused on using it as one of the parental species. Clethra acuminata and C. fargesii were chosen as parents because of their ornamental bark characteristics (Bir, 1992; Krüssman, 1976). Clethra acuminata is a medium-sized shrub to small tree that grows on moderately dry, rocky mountainsides in the southeastern U.S., while C. fargesii is a medium-sized shrub that is native to Central China (Dirr, 1998). Both are deciduous, hardy to zone 5, and are members of the same section as $C$. alnifolia. A Mexican species, $C$. pringlei, was chosen to hybridize with $C$. alnifolia because of its glossy, colorful, evergreen foliage. This species can reach up to $8 \mathrm{~m}$ in height, and is hardy to zone 7 (Dirr, 1998).

\section{Materials and Methods}

Plant materials and hybridization. The following taxa were used in this study: $C$. alnifolia 'Alba', 'Fern Valley Pink', 'Hummingbird', and 'Ruby Spice'; C. acuminata; $C$. fargesii; and $C$. pringlei. Plants were obtained from the following sources: Greer
Gardens, Eugene, Ore.; Heronswood Nursery, Kingston, Wash.; Louisiana Nursery, Opelousas, La.; and Roslyn Gardens, Dix Hill, N.Y. (Table 1). For C. acuminata, C. fargesii, and $C$. pringlei, a single plant of each species was used for all controlled pollinations, molecular analysis and morphological measurements. Plants were grown at the Tennessee State Univ. Nursery Crop Research Station in McMinnville, Tenn.; all hybridizations were also conducted at this location.

Plants were grown in 56.8-L containers in pine bark amended with $6.6 \mathrm{~kg} \cdot \mathrm{m}^{-3}$ $19 \mathrm{~N}-2.1 \mathrm{P}-7.4 \mathrm{~K}$ Osmocote fertilizer (ScottsSierra Horticultural Products Co., Maryville Ohio), $0.6 \mathrm{~kg} \cdot \mathrm{m}^{-3}$ Micromax (Scotts-Sierra Horticultural Products Co.), and $0.2 \mathrm{~kg} \cdot \mathrm{m}^{-3}$ Epsom salts. Plants were grown under $60 \%$ shade and microirrigated using spray stakes during the 1998, 1999, and 2000 growing seasons. Each plant was top-dressed with $125 \mathrm{~g} 19 \mathrm{~N}-2.1 \mathrm{P}-6.6 \mathrm{~K}$ Osmocote fertilizer in May 1999 and May 2000. In 1998-99 and 1999-2000, C. acuminata, C. fargesii, and $C$. pringle $i$ were over-wintered in a hoop structure covered with white plastic. Clethra alnifolia plants were moved outside to a potin-pot growing system during winter.

Reciprocal crosses were made between $C$. alnifolia and the other three Clethra species during Summer 1998. Intraspecific crosses were also made between the $C$. alnifolia cultivars. Self-pollinations were made using unemasculated flowers of each species. Finally, as a control, flowers from each of the species were emasculated but not pollinated.

Prior to pollination, open flowers were removed from inflorescences, which were then covered with Del-Net breathable plastic pollination bags (Applied Extrusion Technologies, Middletown, Del.). Flowers to be used as maternal parents were emasculated when we determined, based on flower size and color, that they were 1 to $2 \mathrm{~d}$ from opening. Immature flowers were removed from inflorescences. The inflorescences were recovered, and pollinations made 1 to $2 \mathrm{~d}$ later.

For pollen collection, individual flowers were removed from inflorescences just as the flowers began to open, but before anther dehiscence. Flowers were placed in plastic petri dishes and kept in the laboratory $\left(22\right.$ to $\left.25^{\circ} \mathrm{C}\right)$ for 1 to $2 \mathrm{~h}$. Each flower was held slightly above the surface of the petri dish and tapped lightly with a pair of forceps. Freshly released pollen distributed onto the petri dish by this action was collected onto the tip of a small brush and applied to the stigmas of emasculated flowers. Pollination bags were kept over the inflorescences for 2 weeks after pollination.

The infructescences were collected in late October when the capsules began to dry. They were placed in paper bags and kept at room temperature $\left(22\right.$ to $25^{\circ} \mathrm{C}$ ) until the capsules were completely dry. The capsules were crushed and the seeds separated from the debris using a stereomicroscope. For those capsules that contained many seeds, the tip of the capsule was broken open and the seeds poured into a glassine bag. 
Table 1. Taxa included in this study.

\begin{tabular}{|c|c|c|}
\hline Code no. & Taxa & Source \\
\hline$\overline{1}$ & C. alnifolia Fern Valley Pink & Roslyn Gardens \\
\hline 2 & C. alnifolia Fern Valley Pink $\times C$. pringlei & \\
\hline 3 & C. pringlei & Louisiana Nursery \\
\hline 4 & C. alnifolia Ruby Spice $\times$ C. pringlei $(282 \mathrm{C})$ & \\
\hline 5 & C. alnifolia Ruby Spice $\times$ C. pringlei $(282 \mathrm{~F})$ & \\
\hline 6 & C. alnifolia Ruby Spice $\times$ C. pringlei $(282 \mathrm{G})$ & \\
\hline 7 & C. alnifolia Ruby Spice $\times$ C. pringlei $(282 \mathrm{H})$ & \\
\hline 8 & C. alnifolia Ruby Spice $\times C$. pringlei $(282 \mathrm{~J})$ & \\
\hline 9 & C. alnifolia Ruby Spice & Roslyn Gardens \\
\hline 10 & C. alnifolia Ruby Spice $\times$ C. fargesii (278C) & \\
\hline 11 & C. alnifolia Ruby Spice $\times$ C. fargesii (278D) & \\
\hline 12 & C. fargesii $\times$ C. alnifolia Ruby Spice $(285 \mathrm{~A})$ & \\
\hline 13 & C. fargesii $\times$ C. alnifolia Ruby Spice $(285 \mathrm{~B})$ & \\
\hline 14 & C. fargesii $\times$ C. alnifolia Ruby Spice $(285 \mathrm{G})$ & \\
\hline 15 & C. fargesii $\times$ C. alnifolia Ruby Spice $(285 \mathrm{~J})$ & \\
\hline 16 & C. fargesii & Heronswood Nursery \\
\hline 17 & C. fargesii $\times$ C. alnifolia Hummingbird (284B) & \\
\hline 18 & C. fargesii $\times$ C. alnifolia Hummingbird (284D) & \\
\hline 19 & C. fargesii $\times$ C. alnifolia Hummingbird (284F) & \\
\hline 20 & C. fargesii $\times$ C. alnifolia Hummingbird $(284 \mathrm{H})$ & \\
\hline 21 & C. fargesii $\times$ C. alnifolia Hummingbird (284J) & \\
\hline 22 & C. alnifolia Hummingbird & Roslyn Nursery \\
\hline 23 & C. alnifolia Hummingbird $\times$ C. acuminata & \\
\hline 24 & C. acuminata & Greer Gardens \\
\hline 25 & C. alnifolia Alba $\times$ C. fargesii & \\
\hline 26 & C. alnifolia Alba & Greer Gardens \\
\hline
\end{tabular}

Seeds were stored in glassine bags in a $5^{\circ} \mathrm{C}$ refrigerator for 2 months prior to sowing. Seeds were sown on the surface of a 1 vermiculite : 1 peatmoss mixture in square $(6 \mathrm{~cm})$ plastic pots. Pots were placed in a $26^{\circ} \mathrm{C}, 80 \%$ to $90 \%$ relative humidity incubator under a 12 $\mathrm{h}$ photoperiod, provided by six $110-\mathrm{W}$ coolwhite fluorescent bulbs located $120 \mathrm{~cm}$ above the seed trays. After germination, light intensity was increased by turning on an additional six 110-W cool-white fluorescent bulbs. A water-soluble fertilizer $(7 \mathrm{~N}-3.8 \mathrm{P}-4.1 \mathrm{~K})$ at the rate of $150 \mathrm{ppm} \mathrm{N}$ was used as necessary for watering seedlings. When the second set of true leaves had developed, seedlings were transplanted to individual pots and grown under $60 \%$ shade. Plants were overwintered under white plastic. In Spring 2000, each plant was transplanted to a $26.5-\mathrm{L}$ container, and maintained in the shadehouse.

Molecular analysis. Newly emerged leaf tissue was collected from parental species and from randomly selected hybrid plants in Apr. 2000. DNA was extracted from leaves using the cetyltrimethylammonium bromide (CTAB) method (Doyle and Doyle, 1987). Polymerase chain reaction (PCR) amplification was performed using a 60-well PTC 100 thermocycler (MJ Research, Waltham, Mass.). PCRs were carried out using Ready-To-Go PCR Beads (Amersham Pharmacia Biotech., Piscataway, N.J.) with $25 \mu \mathrm{mol}$ primer and 20 ng genomic DNA. Forty 10-mer random primers (Operon Technologies, Alameda, Calif.) were screened with C. alnifolia 'Ruby Spice', $C$. acuminata, $C$. fargesii, and $C$. pringlei. Twelve primers (A02, A03, A13, A17, B03, $\mathrm{B} 05, \mathrm{~B} 06, \mathrm{~B} 13, \mathrm{C} 02, \mathrm{C} 06, \mathrm{C} 14$, and $\mathrm{C} 20$ ), which were found to produce a large number of polymorphic bands among the parental species, were used to examine the complete set of parental taxa and putative hybrids. An initial denaturation at $94^{\circ} \mathrm{C}$ for 3 min was followed by 35 cycles of $94^{\circ} \mathrm{C}$ for $5 \mathrm{~s}, 37^{\circ} \mathrm{C}$ for $1 \mathrm{~min}$, and $72^{\circ} \mathrm{C}$ for $1 \mathrm{~min}$. The randomly amplified polymorphic DNA (RAPD) fragments were separated by electrophoresis using $1.2 \%$ agarose gel and visualized with ethidium bromide. Each primer-genotype RAPD reaction was performed twice.
P-distance for each comparison was calculated by dividing the number of different bands by the total number of bands. Dendrograms were constructed by neighbor-joining analysis based on p-distance (Saitou and Mei, 1987) using MEGA (Molecular Evolutionary Genetic Analysis) program version 1.0 (Pennsylvania State Univ., University Park).

Morphological measurements. Morphological measurements of putative hybrids and parental species were made during Summer 2000 , using the same plants that were utilized for the molecular analysis. Leaf measurements were made on 10 of the most recently fully expanded leaves. Leaf blade length, leaf width at widest point, and petiole length were determined for each leaf, and a leaf length : width ratio was calculated. Leaf serration, pubescence, and leaf shape were also recorded for each plant. A side-by-side comparison of upper and lower leaf surface color was made for each putative hybrid and its parental species. The length of 10 inflorescences, from the lowest flower to the tip of the raceme, was measured on each plant; this measurement was made when $\approx 75 \%$ of the flowers on the raceme had opened. Flower length, flower width, and pedicle length were measured on 10 newly opened flowers from each plant.

Data for each pair of parental plants and their putative hybrids were analyzed using the general linear model of SigmaStat statistical software, version 2.03 (SPSS, Chicago). When significant $(P \leq 0.05)$ differences among plants were observed, treatment means were separated by Tukey's $t$ test.

\section{Results}

Hybridization. All of the C. acuminata $\mathrm{x}$ C. alnifolia and over $80 \%$ of the C. alnifolia $\mathrm{x} C$. acuminata pollinations produced fruit (Table 2). While none of the C. acuminata $\mathrm{x}$ C. alnifolia seeds germinated, one putative C. alnifolia 'Hummingbird' $\mathrm{x}$ C. acuminata hybrid was obtained. Over half of the crosses between $C$. fargesii and $C$. alnifolia produced fruit. The $C$. fargesii $\times$ C . alnifolia capsules had a mean of 36 seeds per capsule, while only four seeds per capsule were obtained from the reciprocal cross. From the 108 seedlings that were obtained, 20 C. fargesii $\mathrm{x}$ C. alnifolia and 6 C. alnifolia $\times$ C. fargesii

Table 2. Fruit set, seed set and seed germination resulting from interspecific crosses involving four Clethra species

\begin{tabular}{|c|c|c|c|c|c|c|}
\hline Maternal parent & $\begin{array}{l}\text { Pollen } \\
\text { source }\end{array}$ & $\begin{array}{l}\text { No. flowers } \\
\text { pollinated }\end{array}$ & $\begin{array}{l}\text { No. fruit } \\
\text { set }\end{array}$ & $\begin{array}{l}\text { No. seed } \\
\text { produced }\end{array}$ & $\begin{array}{c}\text { Seed } \\
\text { germination } \\
(\%)\end{array}$ & $\begin{array}{l}\text { No. plants } \\
\text { transplanted }\end{array}$ \\
\hline C. acuminata & C. alnifolia Hummingbird & 8 & 8 & 22 & 0 & --- \\
\hline C. acuminata & C. alnifolia Ruby Spice & 10 & 10 & 103 & 0 & --- \\
\hline C. alnifolia Hummingbird & C. acuminata & 12 & 10 & 5 & 20 & 1 \\
\hline C. fargesii & C. alnifolia Hummingbird & 22 & 15 & 616 & 4 & 10 \\
\hline C. fargesii & C. alnifolia Ruby Spice & 41 & 27 & 892 & 8 & 10 \\
\hline C. alnifolia Alba & C. fargesii & 43 & 25 & 98 & 6 & 2 \\
\hline C. alnifolia Ruby Spice & C. fargesii & 35 & 19 & 86 & 6 & 4 \\
\hline C. pringlei & C. alnifolia Fern Valley Pink & 46 & 0 & --- & --- & --- \\
\hline C. pringlei & C. alnifolia Ruby Spice & 80 & 0 & --- & --- & --- \\
\hline C. alnifolia Fern Valley Pink & C. pringlei & 42 & 36 & 5 & 20 & 1 \\
\hline C. alnifolia Hummingbird & C. pringlei & 33 & 22 & 8 & 12 & 0 \\
\hline C. alnifolia Ruby Spice & C. pringlei & 148 & 85 & 106 & 11 & 11 \\
\hline
\end{tabular}


plants survived. No seeds were obtained from the $C$. pringlei $\times$ C. alnifolia crosses. About $64 \%$ of the $C$. alnifolia $\times$ C. pringlei crosses produced fruit, but only about one-third of the fruit contained seeds. Fourteen seeds germinated, but two plants died at the seedling stage.

Over $80 \%$ of the C. alnifolia intraspecific crosses produced seeds, with a mean of 30 seeds obtained per capsule. The seeds had a mean germination rate of $90 \%$, and transplanted seedlings had a $98 \%$ survival rate. About $20 \%$ of the C. alnifolia self-pollinations produced seeds, but none of the resulting 52 seeds germinated. The $C$. acuminata, $C$. fargesii, and C.pringlei self-pollinations, along with the emasculated, unpollinated flowers of all four species, failed to produce seed.

Molecular analysis. The 12 primers described in the materials and methods produced 193 scorable bands ranging in size from 300 to $2000 \mathrm{bp}$. Of these bands, 180 , or $93 \%$, were polymorphic. The banding patterns of the putative hybrids had a high degree of similarity to those of the C. alnifolia cultivars (Fig. 1).

In all cases, p-distance values between putative hybrids and the $C$. alnifolia parent were much smaller than between the hybrids and their other parent (Table 3). As shown in the dendrogram based on these p-distances, the plants examined in this study fell into two main clusters (Fig. 2). One cluster consisted of $C$. acuminata, C. fargesii and $C$. pringlei, whereas the $C$. alnifolia cultivars and putative interspecific hybrids were in the other cluster. Within this second cluster, plants derived from the same set of parents generally clustered together and putative hybrids often clustered close to their $C$. alnifolia parent. Clethra alnifolia 'Fern Valley Pink' was separated from the other $C$. alnifolia cultivars in the dendrogram. 'Fern Valley Pink' was found in a native stand of plants growing in eastern
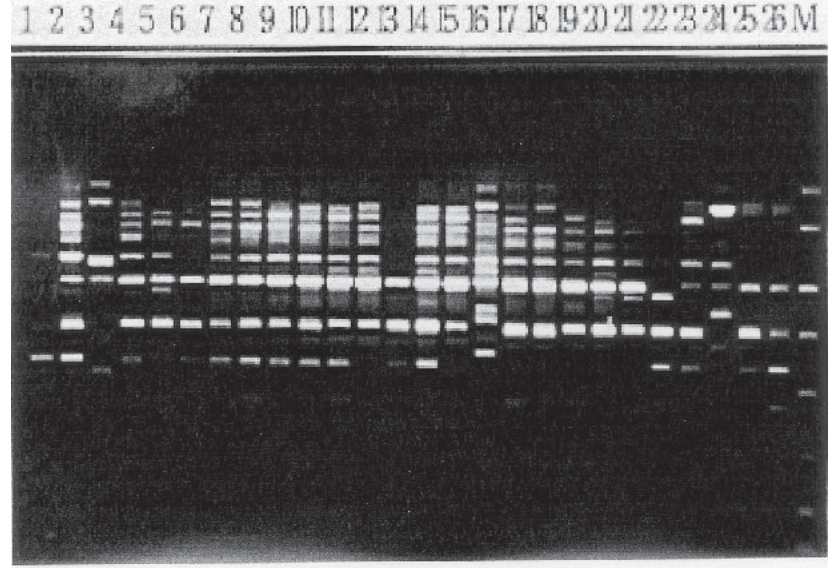

Fig. 1. Agarose gel electrophoresis of DNA fragments obtained by RAPD amplification of Clethra species and putative interspecific hybrids with primer B06. Lanes correspond to code numbers presented in Table 1.

North Carolina, where both C. alnifolia and C. alnifolia var. tomentosa occur (Dirr, 1998). It is possible that 'Fern Valley Pink' is either a var. tomentosa cultivar, an $\mathrm{F}_{1}$ hybrid between the northern and southern forms of C. alnifolia, or the result of introgression between these two forms of $C$. alnifolia.

Morphological measurements. Leaf length, petiole length and lower leaf-surface color of the $C$. alnifolia 'Hummingbird' $\times C$. acuminata putative hybrid were similar to those of $C$. acuminata; however, the plant resembled 'Hummingbird' in upper leaf-surface color and lack of trichomes (data not presented). Leaf length : width ratio, leaf shape and serration pattern of the putative hybrid were intermediate to the parents. Leaf width of the putative hybrid exceeded that of both parents. The putative hybrid had not yet flowered, so inflorescence and flower comparisons could not be made.
For most morphological traits measured, the $C$. alnifolia $\times$ C. fargesii and C. fargesii $\mathrm{x}$ C. alnifolia plants examined either resembled C. alnifolia or were intermediate between the two parents (Table 4). However, most of the putative hybrids had at least one quantitative measurement in which they resembled $C$. fargesii. Several putative hybrids resembled C. fargesii in lower leaf-surface color. The degree of leaf serration of all putative hybrids between $C$. fargesii and $C$. alnifolia was similar to that of $C$. fargesii, while leaf shape of the putative hybrids was similar to that of C. alnifolia. All but one of the putative hybrids between $C$. alnifolia and $C$. fargesii were glabrous like $C$. alnifolia. Upper leafsurface color in $C$. alnifolia and $C$. fargesii was too similar to be used to as a distinguishing factor.

One C. alnifolia 'Ruby Spice' $x$ C. pringlei putative hybrid that was selected for molecu-

Table 3. P-distance matrix for Clethra species and putative interspecific hybrids. P-distance $=$ number of different bands/total number of bands. Code numbers correspond to those in Table 1 .

\begin{tabular}{|c|c|c|c|c|c|c|c|c|c|c|c|c|c|c|c|c|c|c|c|c|c|c|c|c|c|}
\hline & 2 & 3 & 4 & 5 & 6 & 7 & 8 & 9 & 10 & 11 & 12 & 13 & 14 & 15 & 16 & 17 & 18 & 19 & 20 & 21 & 22 & 23 & 24 & 25 & 26 \\
\hline 1 & 0.14 & 0.46 & 0.20 & 0.19 & 0.19 & 0.21 & 0.26 & 0.23 & 0.21 & 0.21 & 0.23 & 0.23 & 0.21 & 0.23 & 0.45 & 0.24 & 0.22 & 0.21 & 0.24 & 0.19 & 0.27 & 0.21 & 0.42 & 0.22 & 0.23 \\
\hline 2 & & 0.44 & 0.17 & 0.17 & 0.19 & 0.18 & 0.23 & 0.22 & 0.24 & 0.23 & 0.22 & 0.27 & 0.22 & 0.22 & 0.53 & 0.24 & 0.21 & 0.21 & 0.24 & 0.22 & 0.23 & 0.19 & 0.47 & 0.27 & 0.27 \\
\hline 3 & & & 0.50 & 0.51 & 0.49 & 0.48 & 0.50 & 0.53 & 0.51 & 0.53 & 0.51 & 0.54 & 0.54 & 0.52 & 0.47 & 0.53 & 0.52 & 0.51 & 0.55 & 0.48 & 0.53 & 0.50 & 0.39 & 0.51 & 0.50 \\
\hline 4 & & & & 0.08 & 0.13 & 0.15 & 0.14 & 0.14 & 0.14 & 0.17 & 0.16 & 0.17 & 0.17 & 0.18 & 0.55 & 0.18 & 0.16 & 0.19 & 0.17 & 0.19 & 0.18 & 0.18 & 0.48 & 0.21 & 0.18 \\
\hline 5 & & & & & 0.09 & 0.14 & 0.16 & 0.12 & 0.13 & 0.17 & 0.17 & 0.17 & 0.16 & 0.18 & 0.55 & 0.22 & 0.19 & 0.18 & 0.19 & 0.18 & 0.20 & 0.13 & 0.47 & 0.21 & 0.17 \\
\hline 6 & & & & & & 0.14 & 0.14 & 0.11 & 0.14 & 0.16 & 0.13 & 0.16 & 0.17 & 0.18 & 0.54 & 0.22 & 0.21 & 0.18 & 0.21 & 0.18 & 0.23 & 0.13 & 0.46 & 0.19 & 0.18 \\
\hline 7 & & & & & & & 0.16 & 0.13 & 0.12 & 0.14 & 0.16 & 0.22 & 0.18 & 0.16 & 0.51 & 0.19 & 0.17 & 0.16 & 0.21 & 0.18 & 0.19 & 0.14 & 0.46 & 0.16 & 0.15 \\
\hline 8 & & & & & & & & 0.17 & 0.21 & 0.23 & 0.21 & 0.24 & 0.23 & 0.24 & 0.55 & 0.24 & 0.21 & 0.23 & 0.23 & 0.23 & 0.18 & 0.19 & 0.49 & 0.23 & 0.16 \\
\hline 9 & & & & & & & & & 0.11 & 0.13 & 0.14 & 0.13 & 0.17 & 0.14 & 0.53 & 0.26 & 0.22 & 0.19 & 0.23 & 0.21 & 0.26 & 0.17 & 0.46 & 0.19 & 0.16 \\
\hline 10 & & & & & & & & & & 0.09 & 0.12 & 0.14 & 0.16 & 0.14 & 0.48 & 0.16 & 0.19 & 0.14 & 0.21 & 0.16 & 0.26 & 0.19 & 0.44 & 0.16 & 0.19 \\
\hline 11 & & & & & & & & & & & 0.09 & 0.13 & 0.12 & 0.10 & 0.47 & 0.17 & 0.15 & 0.15 & 0.17 & 0.16 & 0.23 & 0.19 & 0.45 & 0.16 & 0.19 \\
\hline 12 & & & & & & & & & & & & 0.14 & 0.12 & 0.07 & 0.48 & 0.16 & 0.15 & 0.15 & 0.16 & 0.18 & 0.24 & 0.19 & 0.45 & 0.19 & 0.22 \\
\hline 13 & & & & & & & & & & & & & 0.12 & 0.13 & 0.49 & 0.21 & 0.16 & 0.17 & 0.22 & 0.19 & 0.27 & 0.23 & 0.48 & 0.22 & 0.22 \\
\hline 14 & & & & & & & & & & & & & & 0.10 & 0.47 & 0.19 & 0.15 & 0.14 & 0.17 & 0.19 & 0.27 & 0.21 & 0.47 & 0.21 & 0.24 \\
\hline 15 & & & & & & & & & & & & & & & 0.49 & 0.17 & 0.12 & 0.14 & 0.18 & 0.16 & 0.25 & 0.19 & 0.46 & 0.21 & 0.24 \\
\hline 16 & & & & & & & & & & & & & & & & 0.51 & 0.45 & 0.50 & 0.46 & 0.54 & 0.54 & 0.47 & 0.35 & 0.52 & 0.47 \\
\hline 17 & & & & & & & & & & & & & & & & & 0.12 & 0.09 & 0.13 & 0.12 & 0.18 & 0.24 & 0.48 & 0.16 & 0.22 \\
\hline 18 & & & & & & & & & & & & & & & & & & 0.13 & 0.12 & 0.15 & 0.17 & 0.21 & 0.49 & 0.21 & 0.21 \\
\hline 19 & & & & & & & & & & & & & & & & & & & 0.15 & 0.12 & 0.22 & 0.21 & 0.47 & 0.18 & 0.22 \\
\hline 20 & & & & & & & & & & & & & & & & & & & & 0.18 & 0.14 & 0.22 & 0.45 & 0.22 & 0.22 \\
\hline 21 & & & & & & & & & & & & & & & & & & & & & 0.24 & 0.21 & 0.49 & 0.18 & 0.23 \\
\hline 22 & & & & & & & & & & & & & & & & & & & & & & 0.20 & 0.46 & 0.20 & 0.16 \\
\hline 23 & & & & & & & & & & & & & & & & & & & & & & & 0.44 & 0.18 & 0.14 \\
\hline 24 & & & & & & & & & & & & & & & & & & & & & & & & 0.47 & 0.39 \\
\hline 25 & & & & & & & & & & & & & & & & & & & & & & & & & 0.12 \\
\hline
\end{tabular}




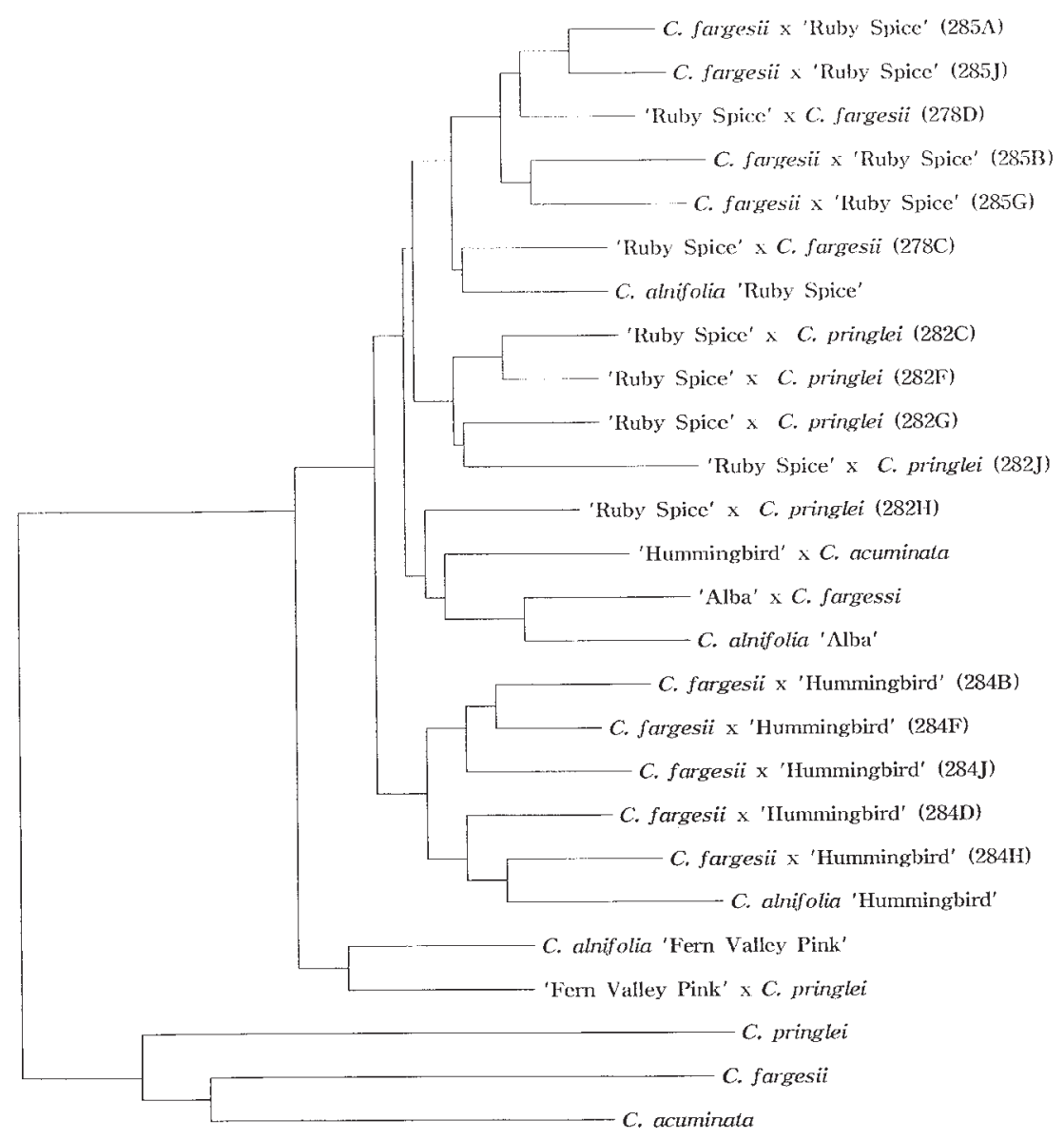

Fig. 2. Dendogram based on neighbor-joining analysis of Clethra species and putative interspecific hybrids using RAPD data.

lar analysis died before the morphological measurements could be made. Most of the quantitative measurements of the remaining C. alnifolia $\times$ C. pringlei plants either were similar to those of $C$. alnifolia or intermediate between the two parents (Table 2). Leaf serration in the putative hybrids was intermediate to that of their parents. Upper and lower leafsurface color, pubescence, and leaf shape were similar in the two parents and among the hybrids.
The C. alnifolia $\times$ C. pringlei plants most closely resembled $C$. pringle $i$ in their autumn and winter foliage characteristics. While the leaves of the $C$. alnifolia cultivars began to develop their autumn coloration in October 1999, and had almost completely defoliated by late-November, the leaves of the C. alnifolia $\mathrm{x} C$. pringlei plants remained green until temperatures dropped below $\approx-5^{\circ} \mathrm{C}$. Rather than abscising, the dead leaves of the C. alnifolia $\mathrm{x}$ C. pringlei plants remained attached to the plants during Winter 1999-2000. The leaves of $C$. pringlei behaved in a similar manner.

\section{Discussion}

Crosses between $C$. alnifolia and three other species with ornamental value resulted in 123 putative hybrids, 39 of which survived past the seedling stage. Plants were obtained from all three interspecific hybrid combinations. Reciprocal crosses between C. alnifolia and $C$. fargesii yielded offspring, while the other two hybrid combinations produced plants only when $C$. alnifolia was used as the maternal parent. The failure to recover plants from C. acuminata $\times$ C. alnifolia hybridizations may have been due to the small number of pollinations made; however, the lack of success in securing a $C$. pringlei $\times C$. alnifolia hybrid was probably not caused by an inadequate number of pollinations.

Interspecific hybridizations with $C$. alnifolia as the maternal parent produced substantially fewer seeds per capsule with a reduced germination rate than did similar intraspecific hybridizations. Although we did not test intraspecific hybridization in the other three species, no germination problems have been noted for Clethra seed (Dirr and Heuser, 1987; Bir, 1992). The lack of viable plants from self-pollinations of the four species greatly reduces the possibility that the plants obtained from the interspecific hybridizations were the result of accidental self-pollinations. An apomictic origin also appears unlikely due to the failure of emasculated, unpollinated flowers to set seed.

Confirmation of the hybrid nature of the plants obtained in this study relied on morphological and molecular comparisons of the putative hybrids with their parents. Morphological evidence of hybridity was found in the sole $C$. alnifolia $\times C$. acuminata plant, which strongly resembled $C$. acuminata in many of the characteristics measured. The hybrid nature of the $C$. fargesii $\times C$. alnifolia plants was also evident in the close morphological similarity of the hybrids to the paternal parent. The $C$. alnifolia $\times C$. fargesii

Table 4. Comparison of morphological traits of Clethra putative interspecific hybrids and parent species. N/a indicates that there was no significant difference between parents for that particular trait.

\begin{tabular}{|c|c|c|c|c|c|c|c|c|c|c|c|}
\hline $\begin{array}{l}\text { Interspecific } \\
\text { hybridization }\end{array}$ & $\begin{array}{c}\text { Leaf } \\
\text { length }\end{array}$ & $\begin{array}{l}\text { Leaf } \\
\text { width }\end{array}$ & $\begin{array}{c}\text { Leaf } \\
\text { length : } \\
\text { width }\end{array}$ & $\begin{array}{c}\text { Inflorescence } \\
\text { length }\end{array}$ & $\begin{array}{l}\text { Flower } \\
\text { length }\end{array}$ & $\begin{array}{c}\text { Flower } \\
\text { width }\end{array}$ & $\begin{array}{l}\text { Pedicle } \\
\text { length }\end{array}$ & $\begin{array}{c}\text { Lower } \\
\text { leaf-surface } \\
\text { color }\end{array}$ & $\begin{array}{c}\text { Leaf } \\
\text { serration }\end{array}$ & $\begin{array}{l}\text { Leaf } \\
\text { shape }\end{array}$ & Pubescence \\
\hline \multicolumn{12}{|l|}{ C. alnifolia $\times$ C. fargesii } \\
\hline No. plants intermediate to parents & 1 & 2 & & 1 & & 1 & & & & & \\
\hline No. plants resembling $C$. fargesii & 1 & & 2 & & & & 1 & 1 & 3 & & \\
\hline \multicolumn{12}{|l|}{ C. fargesii $\times$ C. alnifolia } \\
\hline No. plants resembling C. alnifolia & 3 & 3 & 5 & 2 & 8 & 7 & 9 & 4 & & 9 & 8 \\
\hline C. alnifolia $\times$ C. pringlei & & & $\mathrm{n} / \mathrm{a}$ & & & & & $\mathrm{n} / \mathrm{a}$ & & $\mathrm{n} / \mathrm{a}$ & $\mathrm{n} / \mathrm{a}$ \\
\hline No. plants resembling $C$. alnifolia & 3 & 2 & & & 3 & 3 & 1 & & & & \\
\hline No. plants intermediate to parents & 1 & & & 2 & & & 2 & & & & \\
\hline No. plants resembling C. pringlei & 1 & 3 & & 1 & & & & & 5 & & \\
\hline
\end{tabular}

${ }^{2}$ For the morphological measurements, a putative hybrid was classified as resembling a parent if there was no statistical difference between it and that parent or if the measurement of the putative hybrid statistically exceeded that of the parent. A putative hybrid was classified as intermediate to parents if there was no statistical difference between it and either parent or if its measurement was statistically different from and intermediate to that of both parents. Mean separation was based on Tukey's $t$ test $(P \leq 0.05)$. 
plants were similar in appearance to $C$. alnifolia, but no more than was the reciproca hybrid; therefore, it was not possible to confirm or deny hybridity in these plants based on morphological comparisons. While the $C$. alnifolia $\times$ C. pringlei putative hybrids resembled $C$. alnifolia more strongly than they $\operatorname{did} C$. pringlei, the influence of the evergreen $C$. pringlei was apparent in the autumn and winter foliage characteristics of the $C$. alnifolia $\times C$. pringlei plants. The influence of $C$. acuminata, C. fargesii, and C. pringlei was also seen in the leaf serration of all putative hybrids. Many of the distinguishing characteristics of $C$. fargesii and $C$. pringlei, such as exfoliating bark and height, are not expressed until plants mature. As the hybrids get older, they may resemble one of their parental species in characteristics that were not measured in this study.

The morphological similarity of an interspecific hybrid to one of its parental species can be due to differences in ploidy levels between the two parental species. The basic chromosome number in Clethra is reported to be $\mathrm{n}=8$ (Darlington and Wylie, 1956). Both $C$. alnifolia and C. acuminata are tetraploids with chromosome numbers of $2 n=32$ (Tanaka and Oginuma, 1980). However, since chromosome number has not been reported for $C$. fargesii or C. pringlei, it is not possible to speculate if differences in ploidy level are responsible for the closer resemblence of the putative hybrids to $C$. alnifolia than to $C$. fargesii or $C$. pringlei.

All of the hybrids evaluated in this study had more RAPD markers in common with $C$. alnifolia than with their other parent, even when $C$. alnifolia was the paternal parent. RAPDs are usually dominant markers inherited in a simple Mendelian fashion (Welsh and
McClelland, 1990; Williams et al., 1990). However, since the amplification reaction is determined in part by competition for priming sites in the genome, RAPD patterns may be affected by genetic background (Williams et al., 1993). Aberrations in the banding pattern of Solanum somatic hybrids were theorized to be due to competition in the PCR reaction resulting from the combination of two different templates (Baird, 1992). It may be possible that, when placed in combination in an interspecific hybrid, the $C$. alnifolia genome is amplified more efficiently than the genomes of $C$. acuminata, $C$. fargesii, and $C$. pringlei. However, it should also be considered that the use of additional or different primers might have yielded banding patterns in the Clethra hybrids that were more fully representative of both parents.

There was congruence between morphological and molecular comparisons of hybrids and parents. Based on a combination of morphological and molecular information, the C. alnifolia $\times$ C. acuminata, C. fargesii $\times C$. alnifolia, and C. alnifolia $\times$ C. pringlei plants obtained in this study appear to be of interspecific origin. This is the first report of controlled interspecific hybridization in Clethra, and of the use of molecular markers for determining genetic relationships among members of the genus. While a complete assessment of fertility level in the hybrids has not yet been made, viable $\mathrm{F}_{2}$ seed has been obtained from both the $C$. fargesii $\times C$. alnifolia and $C$. alnifolia $\times C$. pringlei hybrids. The hybrids obtained in this study will be used to develop new Clethra cultivars with improved bark and foliage characteristics. Additional hybridizations, particularly ones utilizing extremely ornamental species such as $C$. arborea and $C$. delavayi, will also be attempted.

\section{Literature Cited}

Baird,E., S. Cooper-Bland, R. Waugh, M. DeMaine, and W. Powell. 1992. Molecular characterization of inter-and intra-specific somatic hybrids of potato using randomly amplified polymorphic DNA (RAPD) markers. Mol. Gen. Genet. 233:469-475.

Bir, R.E. 1992. Native spice. Amer. Nurseryman 175:51-59.

Darlington, C.D. and A.P. Wylie. 1956. Chromosome atlas of flowering plants. Macmillan, New York.

Dirr, M.A. 1998. Manual of woody landscape plants. Stipes Publishing, Champaign, Ill.

Dirr, M.A. and C.W. Heuser, Jr. 1987. The reference manual of woody plant propagation: From seed to tissue culture. Varsity Press, Athens, Ga.

Doyle, J.J. and J.L. Doyle. 1987. A rapid DNA isolation procedure for small quantities of fresh leaf tissue. Phytochem. Bul. 19:11-15.

Hu, S.-Y. 1960. A revision of the genus Clethra in China. J. Arnold Arbor. 41:164-190.

Rehder, A. 1987. Manual of cultivated trees and shrubs. Vol. 1. Dioscorides Press, Portland, Ore.

Saitou, N. and M. Mei. 1987. The neighbour-joining methods: A new method of reconstructing phylogenetic trees. Mol. Biol. Evolution 4:406-425.

Sleumer, H. 1967. Monographia Clethracearum. Bot. Jahrb. Syst. 87:36-116.

Tanaka, R. and K. Oginuma. 1980. Karyomorphological studies on Clethra barbinervis and two allied species. J. Jpn. Bot. 55:65-72.

Welsh, J. and M. McClelland. 1990. Fingerprinting genomes using PCR with arbitrary primers. Nucleic Acids Res. 18:7213-7218.

Wilbur, R.L. and H.A. Hespenheide. 1967. The genus Clethra (Clethraceae) in the United States. Jour. Elisa Mitchell Soc. 83:82-88.

Williams, J.G.K., A.R. Kubelik, K.J. Livak, J.A. Rafalski, and S.V. Tingey. 1990. DNA polymorphisms amplified by arbitrary primers are useful as genetic markers. Nucleic Acids Res. 18:6531-6535.

Williams, J.G.K, M.K. Hanafey, J.A. Rafalski, and S.V. Tingey. 1993. Genetic analysis using random amplified polymorphic markers. Methods Enzymol. 218:704-740. 